\title{
Assessment of Traditional Rainwater Harvesting System in Barren Lands of a Semi-Arid Region
}

\author{
Basant Yadav ${ }^{1}$, Nitesh Patidar ${ }^{2}$, Anupma Sharma ${ }^{2}$, Niranjan Panigrahi ${ }^{3}$, Rakesh Sharma ${ }^{4}$, \\ Vijay Loganathan $^{5}$, GOPAL KRISHAN ${ }^{6}$, Jaswant Singh ${ }^{1}$, Suraj Kumar ${ }^{2}$, and Alison \\ Parker $^{3}$ \\ ${ }^{1}$ Indian Institute of Technology Roorkee \\ ${ }^{2}$ National Institute of Hydrology \\ ${ }^{3}$ Cranfield University \\ ${ }^{4}$ IIT Jodhpur \\ ${ }^{5}$ IIT Ropar \\ ${ }^{6}$ NATIONAL INSTITUTE OF HYDROLOGY
}

January 25, 2021

\begin{abstract}
In semi-arid and arid regions, groundwater is the primary source for domestic, agricultural, and industrial supply. Scattered and erratic rainfall in these regions makes groundwater recharge more complex. Small-scale rainwater harvesting using both traditional and modern rainwater harvesting structures has been seen as a solution to the deepening groundwater crisis in India. In this study, shallow infiltration ponds locally known as Chaukas were studied to understand their groundwater recharge role and pastureland development. Potential groundwater recharge from these shallow infiltration ponds was estimated using the HYDRUS-1D model, simulating the sub-surface processes in the root zone. Field data collected in the year 2019 is used to calibrate the model for field conditions, while monsoon period data (July-August) of 2020 is used to validate the developed model. The developed model was then used to predict the potential groundwater recharge for the monsoon periods of the year 2019 and 2020. The shallow infiltration ponds allow approximately $5 \%$ additional rainfall to be available as potential recharge. The near soil surface moisture also helps develop natural grass cover used for pasture in the early dry periods. Analysis of the vegetation in the past 10 years suggests that these shallow infiltration ponds have converted barren lands into eco-hydrologically productive pasturelands. These Chauka systems have helped in sustainable water resources management in these water stressed regions along with the additional livelihood support through developed pasturelands for animal husbandry. They have potential wide application across India and beyond, as they simply require slightly sloping, barren land above an unconfined aquifer.
\end{abstract}

\section{Hosted file}

Main Draft.pdf available at https://authorea.com/users/391559/articles/505625-assessment-oftraditional-rainwater-harvesting-system-in-barren-lands-of-a-semi-arid-region

\section{Hosted file}

Fig1.pdf available at https://authorea.com/users/391559/articles/505625-assessment-oftraditional-rainwater-harvesting-system-in-barren-lands-of-a-semi-arid-region

\section{Hosted file}

Fig2.pdf available at https://authorea.com/users/391559/articles/505625-assessment-oftraditional-rainwater-harvesting-system-in-barren-lands-of-a-semi-arid-region 


\section{Hosted file}

Fig3.pdf available at https://authorea.com/users/391559/articles/505625-assessment-oftraditional-rainwater-harvesting-system-in-barren-lands-of-a-semi-arid-region

\section{Hosted file}

Fig4.pdf available at https://authorea.com/users/391559/articles/505625-assessment-oftraditional-rainwater-harvesting-system-in-barren-lands-of-a-semi-arid-region

\section{Hosted file}

Fig5.pdf available at https://authorea.com/users/391559/articles/505625-assessment-oftraditional-rainwater-harvesting-system-in-barren-lands-of-a-semi-arid-region

\section{Hosted file}

Fig6.pdf available at https://authorea.com/users/391559/articles/505625-assessment-oftraditional-rainwater-harvesting-system-in-barren-lands-of-a-semi-arid-region

\section{Hosted file}

Fig7.pdf available at https://authorea.com/users/391559/articles/505625-assessment-oftraditional-rainwater-harvesting-system-in-barren-lands-of-a-semi-arid-region

\section{Hosted file}

Fig8.pdf available at https://authorea.com/users/391559/articles/505625-assessment-oftraditional-rainwater-harvesting-system-in-barren-lands-of-a-semi-arid-region

\section{Hosted file}

Fig9.pdf available at https://authorea.com/users/391559/articles/505625-assessment-oftraditional-rainwater-harvesting-system-in-barren-lands-of-a-semi-arid-region

\section{Hosted file}

Fig10.pdf available at https://authorea.com/users/391559/articles/505625-assessment-oftraditional-rainwater-harvesting-system-in-barren-lands-of-a-semi-arid-region

\section{Hosted file}

Fig11.pdf available at https://authorea.com/users/391559/articles/505625-assessment-oftraditional-rainwater-harvesting-system-in-barren-lands-of-a-semi-arid-region

\section{Hosted file}

Fig12.pdf available at https://authorea.com/users/391559/articles/505625-assessment-oftraditional-rainwater-harvesting-system-in-barren-lands-of-a-semi-arid-region

\section{Hosted file}

Table 1.pdf available at https://authorea.com/users/391559/articles/505625-assessment-oftraditional-rainwater-harvesting-system-in-barren-lands-of-a-semi-arid-region

\section{Hosted file}

Table 2.pdf available at https://authorea.com/users/391559/articles/505625-assessment-oftraditional-rainwater-harvesting-system-in-barren-lands-of-a-semi-arid-region

\section{Hosted file}

Table 3.pdf available at https://authorea.com/users/391559/articles/505625-assessment-oftraditional-rainwater-harvesting-system-in-barren-lands-of-a-semi-arid-region 


\section{Hosted file}

Table 4.pdf available at https://authorea.com/users/391559/articles/505625-assessment-oftraditional-rainwater-harvesting-system-in-barren-lands-of-a-semi-arid-region

\section{Hosted file}

Table 5.pdf available at https://authorea.com/users/391559/articles/505625-assessment-oftraditional-rainwater-harvesting-system-in-barren-lands-of-a-semi-arid-region

\section{Hosted file}

Table 6.pdf available at https://authorea.com/users/391559/articles/505625-assessment-oftraditional-rainwater-harvesting-system-in-barren-lands-of-a-semi-arid-region

\section{Hosted file}

Table 7.pdf available at https://authorea.com/users/391559/articles/505625-assessment-oftraditional-rainwater-harvesting-system-in-barren-lands-of-a-semi-arid-region 